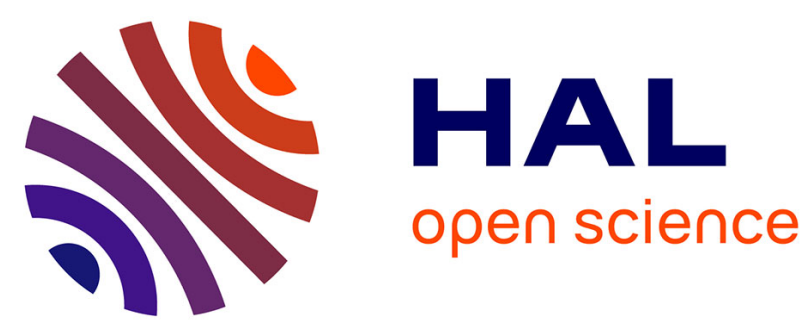

\title{
Where are the landfilled zones? Use of historical geographic information and local spatial knowledge to determine the location of underground asbestos contamination in Sibaté (Colombia)
}

Benjamin Lysaniuk, María Fernanda Cely-García, Agata Mazzeo, Daniela Marsili, Roberto Pasetto, Pietro Comba, Juan Pablo Ramos-Bonilla

\section{To cite this version:}

Benjamin Lysaniuk, María Fernanda Cely-García, Agata Mazzeo, Daniela Marsili, Roberto Pasetto, et al.. Where are the landfilled zones? Use of historical geographic information and local spatial knowledge to determine the location of underground asbestos contamination in Sibaté (Colombia). Environmental Research, 2020, 191, pp.110182. 10.1016/j.envres.2020.110182 . halshs-03065715

\author{
HAL Id: halshs-03065715 \\ https://shs.hal.science/halshs-03065715
}

Submitted on 17 Jan 2022

HAL is a multi-disciplinary open access archive for the deposit and dissemination of scientific research documents, whether they are published or not. The documents may come from teaching and research institutions in France or abroad, or from public or private research centers.
L'archive ouverte pluridisciplinaire HAL, est destinée au dépôt et à la diffusion de documents scientifiques de niveau recherche, publiés ou non, émanant des établissements d'enseignement et de recherche français ou étrangers, des laboratoires publics ou privés. 
Where are the landfilled zones? Use of historical geographic information and local spatial knowledge to determine the location of underground asbestos contamination in Sibaté (Colombia).

Benjamin Lysaniuk ${ }^{1}$, Maria Fernanda Cely Garcia ${ }^{2}$, Agata Mazzeo ${ }^{3}$, Daniela Marsili, ${ }^{4}$, Roberto Pasetto $^{4,5}$, Pietro Comba ${ }^{4,5}$ and Juan Pablo Ramos Bonilla ${ }^{2}$

1 - IRD (MàD par le CNRS), UMR Prodig, Paris, France.

2 - Department of Civil and Environmental Engineering, School of Engineering, Universidad de Los Andes, Bogotá, Colombia.

3 - Department of History and Cultures, University of Bologna, Bologna, Italy

4 - Department of Environment and Health, Istituto Superiore di Sanità, Rome, Italy

5 - WHO Collaborating Centre for Environmental Health in Contaminated Sites, Istituto Superiore di Sanità, Rome, Italy

Abbreviations ${ }^{1}$

\footnotetext{
${ }^{1}$ ACM: Asbestos containing material; AIHA: American Industrial Hygiene Association; ASTM: American Society for Testing and Materials; Chry: Chrysotile; Cro: Crocidolite; DANE, Departamento Administrativo Nacional de Estadística / National Administrative Department of Statistics; GIS: Geographic Information System; IARC: international Agency for Research on Cancer; IGAC: Instituto Geográfico Agustín Codazzi / Agustín Codazzi Geographic Institute; MPM, Malignant Pleural Mesothelioma; PCM: Phase Contrast Microscopy; PLM: Polarized Light Microscopy; TEM: Transmission Electron Microscopy; US EPA: United States Environmental Protection Agency.
} 


\begin{abstract}
Introduction. Sibate is a municipality located in the central region of Colombia, where the first asbestos-cement facility of the country has been in operation since 1942. Both a malignant pleural mesothelioma cluster and landfilled zones with the presence of an underground friable asbestos layer have been identified in Sibaté. There is still limited knowledge regarding the history of the construction of landfilled zones, and what kinds of materials were deposited. The current study aims to improve our understanding of the history and characteristics of the landfilled zones present in Sibaté.
\end{abstract}

Methods. Two participatory workshops with inhabitants of Sibate were conducted to determine when the landfilled zones were built and their location. Information collected in participatory workshops was crossed with both topographic maps and aerial photographs, giving special attention to zones within the urban area of the municipality that in the past were inundated with water from El Muña Reservoir. An opportunistic soil sampling campaign was conducted in suspected landfilled zones that had not been previously sampled, during the replacement of pipelines of the drainage system ordered by the municipality.

Results. The analysis of historic topographic maps, combined with the interpretation of aerial photographs, confirmed the disposal of residues in areas that were previously inundated with water from El Muña Reservoir, creating landfilled zones in the urban area of Sibaté. On top of these landfilled zones, a football stadium and a football field with an athletic track were built. The location of landfilled zones identified using geographic analysis was similar to the location identified analyzing maps constructed by inhabitants of Sibaté in participatory workshops. The four soil samples collected during an opportunistic sampling campaign confirmed the presence in new locations of the underground friable asbestos layer discovered in previous studies.

Discussion. Based on the extension of the landfilled zones, the presence of friable asbestos in these areas, and the close proximity to a school and residential dwellings, there could have been major dispersion events of asbestos fibers in the urban area of Sibate during the disposal of residue materials and the construction of the landfilled zones. Thus, important asbestos exposures may have occurred among residents of Sibaté, which is aggravated by the fact that during those years, more than $50 \%$ of the population of Sibaté was 25 years old or younger. Although the results of the current study improved our understanding of the processes and chronology associated with the landfilled zones, the uncertainty regarding their exact location remains significant. It is important to continue investigating the adverse health effects resulting from this potential asbestos exposure source.

\title{
Keywords
}

Asbestos; Environmental exposure; Historical topographic maps; Aerial photographs; Participatory workshops; Landfilled zones; Sibaté; Colombia 


\section{Introduction}

Asbestos is a term that refers to two types of silicates with fibrous textures: serpentines (i.e., chrysotile) and amphiboles (i.e., crocidolite, amosite, tremolite, actinolite, anthophyllite) [1] [2] [3]. Because of their size, these fibers can be easily inhaled, and can reach and settle in different parts of the respiratory tract, including the alveoli [1]. Asbestos exposure can cause multiple diseases, including non-neoplastic pathologies such as asbestosis, pleural plaques, or pleural thickening, and malignant diseases including cancer of the lung, larynx, and ovaries and mesothelioma [1]. The adverse health effects of asbestos were identified during the $20^{\text {th }}$ century [4] [5] [6], and in 1977 all asbestos forms were classified as a Group 1 Carcinogen (i.e., carcinogenic to humans) by the International Agency for Research on Cancer (IARC) [7] [8]. Based on available scientific evidence, genetic predisposition per se is not currently recognized as an independent causal factor for malignant mesothelioma, but it could enhance the health impact of asbestos exposure and also modulate the patients' response to pharmacological therapies [9] [10]. Because of their physicochemical characteristics, asbestos have been widely used in many products, including building and insulation materials (e.g., corrugated roof sheets, water pipes), and auto-parts (e.g., brake pads, brake linings, clutch disks). The extensive and global use of asbestos was the result of a multifaceted industry in charge of the extraction, packaging, transport, and transformation of the material into commercial products. In July 2019 asbestos was banned in Colombia, and the law will come into effect on January $1^{\text {st }}, 2021$.

The current study is preceded by two publications analyzing the asbestos problem in the municipality of Sibaté, Colombia [11] [12]. In 1942 an asbestos-cement facility was built in Sibaté, a municipality located about 25 kilometers southwest of Bogotá, the Colombian capital [13]. The plant is located 5 $\mathrm{Km}$ north of the urban area of Sibaté, within the jurisdiction of the municipality. The facility is still in operation and has processed asbestos since 1942. It had manufactured both asbestos-cement pipes and corrugated asbestos-cement sheets, but in recent years only corrugated asbestos-cement sheets have been manufactured. Sibaté is a young municipality with a population of 40000 inhabitants approx. [14]. Until 1967, Sibaté was part of another municipality called Soacha [15]. Between the urban area of Sibate and the asbestos-cement facility there is a water reservoir called El Muña, built in the 1940s [16] [17]. At its maximum extension, the reservoir encircled an important part of the urban area of Sibaté (see Supplementary Material 1 for a detailed explanation). In a recent study, both a mesothelioma cluster and an underground friable asbestos layer were discovered in Sibaté [11]. Information collected in door-to-door questionnaires administered in four neighborhoods of Sibate suggested that in some parts of the urban area of the municipality landfilled zones were built, something that was later confirmed with geographical analysis and a participatory workshop conducted with inhabitants of the town [12]. Based on the evolution of the urban zone and changes in topographic height of the urban area of Sibaté, "probable" and "possible" landfilled areas were identified comparing a 1978 topographic map to an actual satellite image, which was complemented with a topographic analysis [11]. "Probable" landfilled zones correspond to former inundated areas, and "possible" landfilled zones refer to areas that are slightly lower in topographic height compared to the surrounding area. Soil samples collected within or near landfilled zones confirmed the presence of an underground friable asbestos layer close to the football stadium, in a football field with athletic track and in an elementary school [11]. The history of the landfills and the reasons for their construction cannot be disassociated from the history of El Muña Reservoir. The first evidence of the project to build the reservoir dates back to the early 1930s, while the construction process began about ten years later [18], and the water filling process may have occurred in the mid-1940s. Soon after a yachting club was established [19] and sport-fishing activities were developed. As a result, during the 1950s the region experienced a significant increase in its economic activity [17]. 
The situation changed drastically in 1967 (i.e., the same year Sibaté became an independent municipality), when the Bogotá Energy Company (EEB) decided to pump the water from the heavily polluted Bogotá River into El Muña reservoir for energy generation purposes [16] [17]. Among other contaminants, the Bogotá River had high concentrations of heavy metals and organic matter, and because of this, the yachting club was relocated to another water body [19] and the reservoir stopped being a recreational and tourist attraction. Strong odors began to spread around the reservoir, and as a remediation response against pollution, an aquatic plant, Eichhornia crassipes (i.e., known as "el buchón"), was introduced [16]. The aquatic plant generated an adequate habitat for mosquito population, increasing its number. Both the mosquitoes and odors prompted the construction of dykes to displace the water from the urban area, desiccating the water. Afterwards, residue materials were disposed in the areas where water was previously present, and later these deposits were compacted creating the landfilled zones where a football stadium and a football field with an athletic track were built [11].

Since in the previous study described above a single map was used, changes over time of these landfilled zones were not determined. For risk management purposes it is important to improve our understanding of the location and history of these landfilled zones. Although seldomly used for this purpose, aerial photographs can be useful for understanding the chronology of an urbanization process [20]. Aerial photographs have also been used to identify potential areas suitable for the construction of landfills [21] or, if we consider the frame of the current study, in the detection and analysis of landfilled zones [22] [23]. Historical geographical information can be important in the identification of risk areas [24] and combined with GIS, can determine spatial changes over time [25]. The tools previously mentioned can be complemented with the knowledge of local inhabitants for the location of health risks, as it has been proposed by Mc Call [26]. Although these methodological approaches were originally conceived for understanding, mapping or managing natural risks [27] [28] [29], they have also been used to understand land use evolution [30] [31] [32].

The current study aims to confirm the presence of landfilled zones in Sibaté. Since a friable asbestos layer was previously found at several points of the "probable" and "possible" landfilled zones, the use of soil samples to determine more precisely the boundaries of the landfills was discarded because of the risk of dispersion of asbestos fibers if the friable asbestos layer is disrupted. Thus, in this study geographic information (i.e., old topographic maps and aerial photographs) and information collected in participatory workshops with local residents, were combined to improve our understanding of the potential location of landfilled zones and the timing of their construction.

\section{Materials and Methods}

This work combines several sources of information and different methods, including the identification of historical geographic information and its analysis using GIS, the organization of workshops in which participatory mapping exercises were conducted, and the opportunistic collection of soil samples and its laboratory analysis.

Initially and to characterize the topography of the area studied a DEM was used (USGS, SRTM, 1 arcsecond $\sim 30$ meters). The contour lines of the area of interest were derived from the raster using the "raster to polyline" tool in a GIS software (Arcgis 10.4 - ESRI (C). To determine the evolution of land uses in the region, all the relevant and available topographic maps of the area of interest from the 1950 s to the 1990s were collected and analyzed. For this, estimated dates of the construction of the landfilled zones in the urban area of Sibate were initially determined from the surveys of the first study [11]. Once the area of interest was identified (i.e., 246-II-C-2), the corresponding digital maps available (i.e., 1950, 1978, and 1989) at a scale 1:10000 were obtained from the Colombian 
Geographic Institute (i.e., IGAC - Instituto Geográfico Agustín Codazzi). The digital map from 1965, which partially covered Sibaté, was discarded. To identify the appropriate aerial photographs, the area of interest (i.e., L10) was initially determined using a specific interface of IGAC (https://geoportal.igac.gov.co/contenido/indice-lineas-de-vuelos-aerofotografias-blanco-y-negro).

From the L10 zone, maps corresponding to the flight lines that passed over the urban area of Sibate on a ten-year period were identified. Applying these criteria, the following photographs were initially obtained in TIFF format: 1965 (M 1337-34854 - estimated scale: 1:50000), 1974 (C 1546-41 estimated scale: 1:50000), 1986 (C 2245-356 - scale: 1:9000), 1995 (C 2549-40 - scale: 1:40000), 2005 (C 2760-26 - scale: 1:10810). Photographs were then geo-referenced (Magna-Sirgas, Bogotá Colombia zone) in GIS software (Arcgis 10.4 - ESRI (C), which allowed superimposing them with current satellite images (Digital Globe, 2016) to establish the evolution of the urban area of Sibate and to specify the changes in land use of the previously identified critical zones.

Two participatory workshops with residents of Sibaté complemented the geographical analysis of topographic maps and aerial photographs. The Universidad de Los Andes Ethics Committee reviewed and approved the procedures applied in the participatory workshops. Participants of the workshops were selected using as inclusion criteria being a resident of Sibaté when landfills were constructed, and being old enough to remember the process of residue disposal and/or construction of the landfilled zones. No exclusion criteria were applied. Residents of Sibaté that are collaborating with the current study helped identify inhabitants of Sibate that could have knowledge of the landfills, who were invited by members of the research team to participate in the workshops. No financial or other types of incentives were offered. The participatory workshops were conducted on April 28, 2018 (11 people) and March 30, 2019 (7 people) adapting the methods proposed by Candelo et al. [33] and Rubio et al. [34]. One of the main objectives of the workshops was to determine the location of the landfilled zones, their history and how they were built. The chronology of relevant events in the evolution of the landfilled zones was of particular interest during the workshops. Using boards placed on the walls of the room where the workshops were conducted, participants shared their knowledge regarding questions with several answer options (Supplementary Material 2). Several topics were addressed during the participatory workshop regarding landfills characteristics including the source of the materials, the disposal of the materials, the disposal zones, the dates of disposal, hours of disposal, actors involved, construction process, among others. For the mapping exercise conducted during the participatory workshops, a map showing the urban area of Sibate was given to each participant asking them to draw the landfilled areas (Supplementary Material 3). All the maps constructed during the participatory workshops were scanned and georeferenced. The zones identified as landfills and/or disposal areas were vectorized as a polygon. To identify those areas that were most frequently mentioned by the participants, the number of overlapping polygons was counted applying the technique colloquially known as "spaghetti and meatballs" [35]. Three maps were produced: a map representing how frequently a landfilled area was identified during the participatory workshop of April $28^{\text {th }} 2018$, a map representing how frequently a landfilled area was identified during the participatory workshop of March $30^{\text {th }}$ 2019, and a map representing how frequently the disposal zones were identified during the participatory workshop of March $30^{\text {th }} 2019$. The information extracted from these maps was compared against the maps resulting from the geographical analysis that used topographic maps and aerial photographs.

As previously explained, because of the presence of an underground layer of friable asbestos [11], soil sampling activities associated with the study were discontinued. Nevertheless, during the second semester of 2018 the municipality commissioned the replacement of underground pipelines of the water drainage system, and after warning them of the risks derived from this activity, an opportunistic soil sampling campaign was conducted on the slopes of the excavations (Fig. 1). 
Samples of what could be the friable asbestos layer were collected (Supplementary Material 4). Samples were collected and analyzed by polarized light microscopy (PLM) according to the US EPA 600/R-93-116 [36], ASTM D7521-16 [37] and soil screening guidelines [38]. Analysis was done by an AlHA accredited laboratory in the United States (i.e., Forensic Analytical Laboratories, Hayward, California, USA). All the researchers involved in collecting soil samples used appropriate personal and respiratory protection equipment.
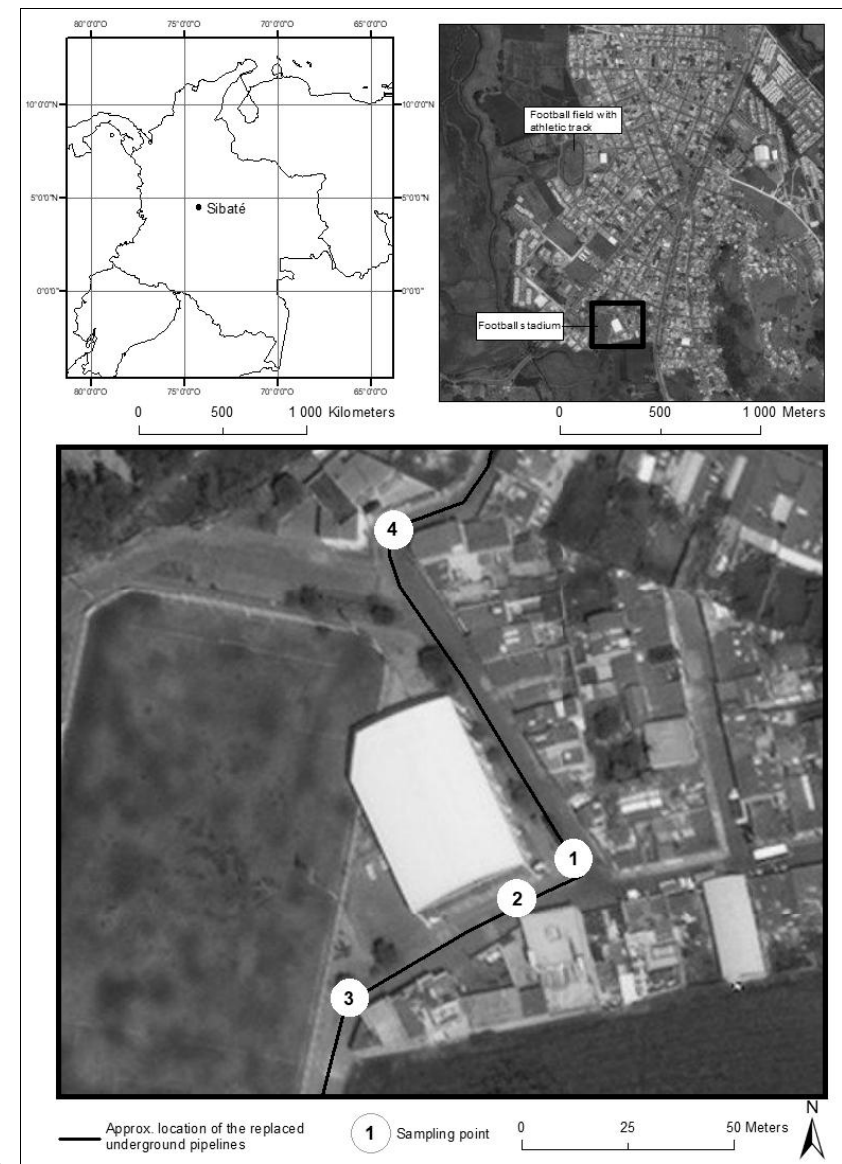

Fig. 1: Location of the four points where samples were opportunistically collected for analysis

\section{Results}

The topographic characteristics of the urban area of Sibaté analyzed using a digital elevation model (Fig. 2), makes it possible to distinguish three zones: a hill (i.e., Cerro La Inmaculada), with urbanized steep slopes on its northern and western flanks (1); a large flat central area corresponding to the oldest and original urban development of Sibaté (2); and some peripheral neighborhoods in the southern, western and northern parts, which were urbanized more recently, where a slight slope is present towards the dark gray areas that correspond to the old, now dried, inundated zones of the reservoir (3). 


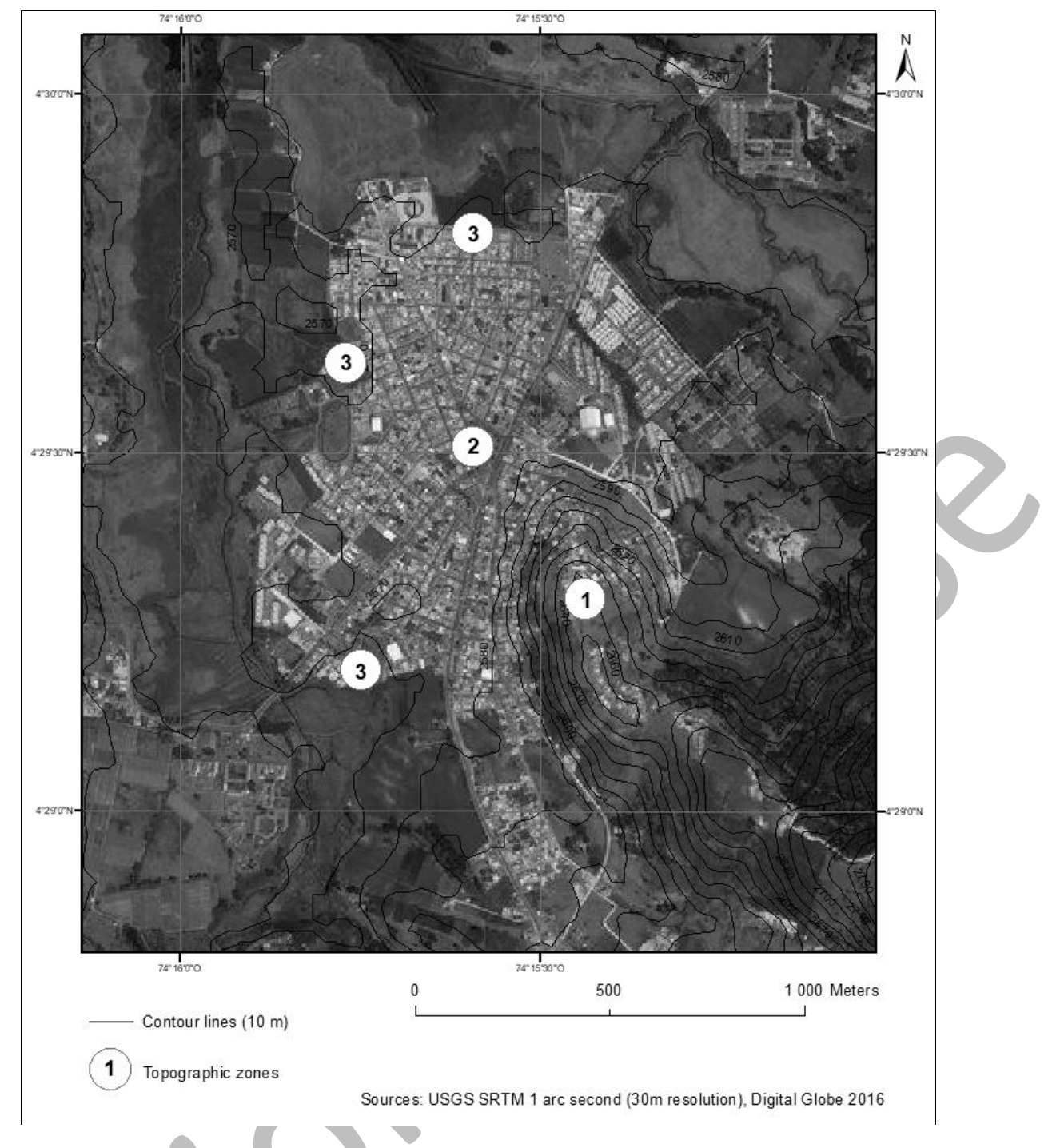

Fig. 2: General topography of the urban area of Sibaté

Topographic maps from different years of the second half of the $20^{\text {th }}$ century show the urban expansion and the densification of the built environment of Sibate (Fig. 3). The central square, where the town hall is currently located, is the center of expansion of Sibaté. The flat areas (sector 2, Fig. 2) were the first to be urbanized, followed by the urbanization of the flanks of the eastern hill (sector 1 , Fig. 2), and finally the low-lying areas of the south, west and north (sector 3, Fig. 2). This urbanization process is accompanied by drastic changes in land-use patterns that are much greater than just new constructions. Thus, on the southern and western flanks of the urban center, important wetlands have disappeared over time. Based on topographic and land-use changes, preliminary evidence indicates that these low areas, corresponding to areas previously inundated with water of the reservoir, were filled with exogenous materials [11]. However, the use of additional topographic maps brings new information including:

- The inundated zones in the urban area of Sibaté were formed when the reservoir was filled.

- At the end of the 1970s, urbanization in the south extended very close to the inundated zones.

- The filling process of the south and west inundated zones of the reservoir occurred at different time periods. 
- By the mid-1980s, inundated zones were not completely dried and the sports facilities (i.e., the stadium and the football field with an athletic track) did not exist.

The comparison against a current satellite image shows that both the football stadium and the football field with an athletic track were built on what used to be topographic depressed zones within the urban area of Sibaté. The north and northeast part of the municipality were also urbanized with new neighborhoods (i.e., west, north and northeast), a bullfight arena (i.e., north), and residential buildings (i.e., west and northwest) (Fig. 3).

Complementing the information obtained from topographic maps with aerial photographs (i.e., one per decade beginning in the 1960s, Fig. 4) it is possible to have a better understanding of the evolution of the urban area of Sibaté since its establishment as an independent municipality. The aerial photographs coincide with the maps, showing a gradual densification from a pre-existing core of dwellings surrounding what is today the Town Hall Square. The added value of the use of aerial photographs is an improved knowledge of the chronological changes in the inundated zones in the south and west areas of the urban area of the town, especially the fact that the disposal of residues in these areas is fairly recent. The photographs from 1965 and 1974 do not suggest residue disposal on these sectors, except for small whitish patches in the 1974 photograph, although these could also be the result of an accumulation of sands and silts.

The aerial photograph of 1986 (Fig. 4) provides novel information regarding the history of the landfilled zones. The asynchrony of the desiccation of the reservoir's water intrusions is confirmed but, contrary to what is suggested by the topographic maps (i.e., Map of 1989 in Fig. 3), the southern intrusion was the first to be filled with residues. On the other hand, the topographic map of 1989 (Fig. 3) also suggests that the process of desiccation of the southern inundated zone had not yet been completed. By 1986 (Fig. 4) two thirds of the topographic depressed zone seems to be filled, and straight lines of anthropogenic origin are observed. These lines may have been created by the trucks that transported the residues to the area and by soil compaction equipment.

The aerial photograph of 1995 (Fig. 4) shows that the desiccation of the water intrusion located on the south is finished and that the football stadium was built on top of this area. This photograph also shows that the desiccation of the western water intrusion was still in process in the mid-1990s.

The aerial photograph of 2005 (Fig. 4) shows that both zones that had been inundated in the past with water from the reservoir have been filled and that sports facilities, still in operation today, have been built: a football field with an athletic track at the west and the football stadium at the south. In summary, the desiccation of the zones that were inundated with waters of the reservoir occurred at different times: the southern intrusion mostly during the late 1980s, and the western intrusion in the mid 1990s. The photographs presented in Fig. 4 suggest that the filling process of inundated zones began sometime between 1974 and 1986. By 1986 more than one hectare of the southern inundated zone had already been filled, although the wetlands are still visible. In 1995, the southern part of the reservoir was drained and approximately 4.2 hectares of another previously inundated area had already been filled. By 2005 the landfilled zones had been completed. The total area that was filled with residues has a size of approximately 4.5 hectares. It is important to recognize that the extension of the landfilled zones could be underestimated, since the estimation of the area of landfilled zones is based on the extension of areas that were previously inundated, which could exclude residues that were deposited to create a smooth transition into the terrains that surround the landfilled zones. 


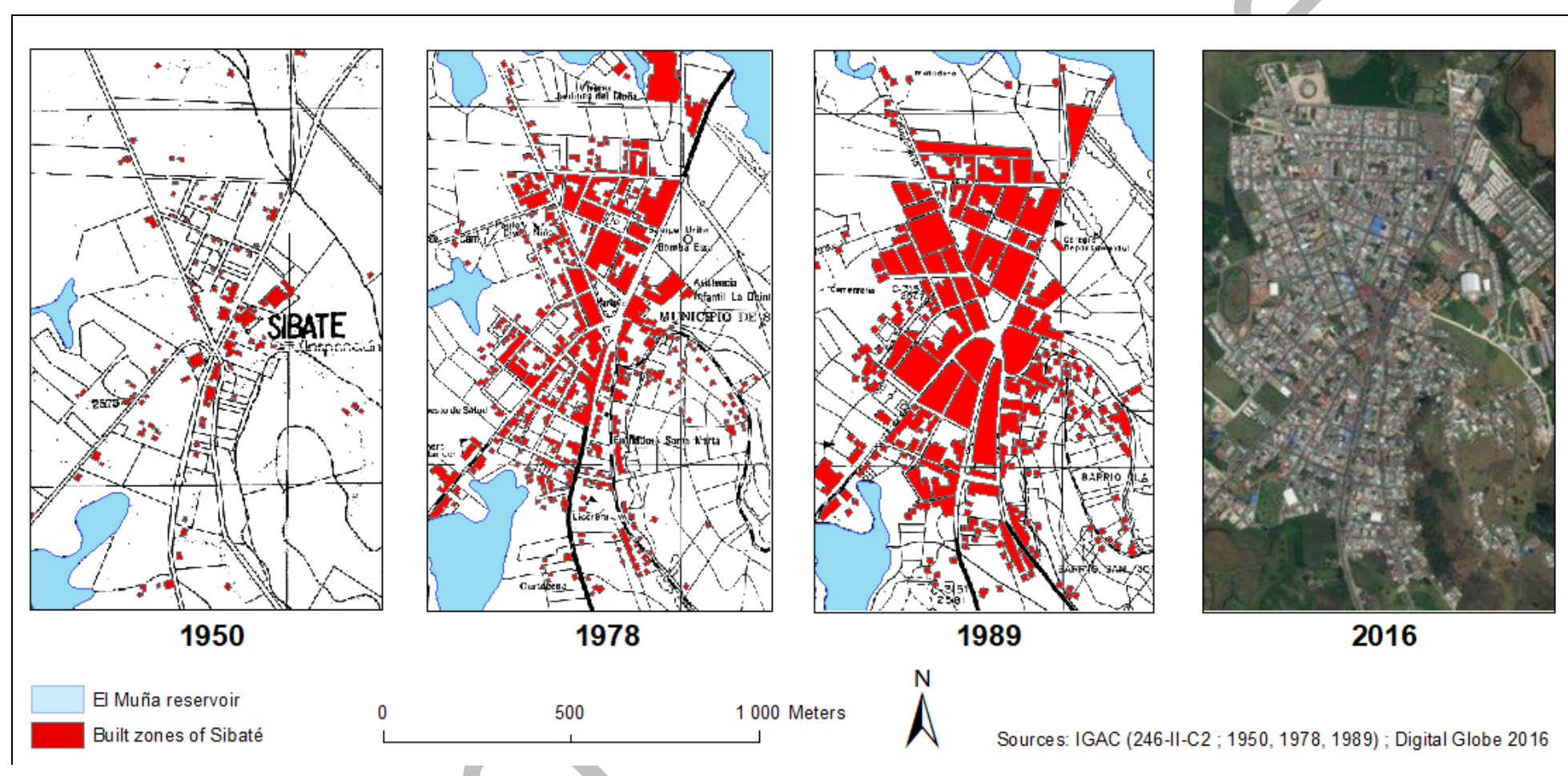

Fig. 3: Evolution of the urban center of Sibate using three topographic maps and a satellite image.

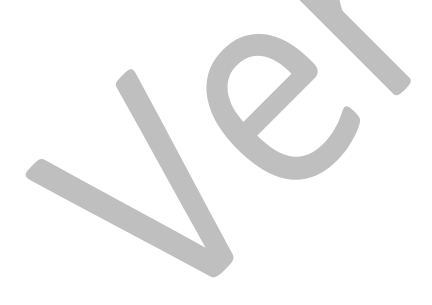


The reconstruction of the process of desiccating and filling the former inundated zones was also done with inhabitants of Sibate in two participatory workshops. Examples of the types of activities and questions asked to the participants of the workshops are presented in Supplementary Material 2. After digitalization and vectorization of the maps elaborated in the participatory workshops, areas of coincidence based on frequency were determined (Fig. 5). An example of a map developed by participants is presented in Supplementary Material 3. Information obtained from the first participatory workshop ( $28^{\text {th }}$ of April 2018; $n=11$; women $=4$; men $=7$, age range: $24-78$ y.o.) confirmed that the current location of the football stadium and the football field with athletic track were critical zones identified by all the participants.

During the workshop of April $28^{\text {th }}, 2018$, some participants sitting side by side shared information when drawing the maps in an activity that was initially planned as an individual task. This may have biased the results, and some areas of Sibaté identified as landfilled zones may have been overrepresented. Furthermore, during this workshop participants made a distinction between "landfilled zones" and "disposal zones", explaining that there were two landfilled zones (i.e., former inundated areas), but there were also other areas where residue materials were deposited. During the second workshop conducted on March 30 2019 ( $n=7$; women $=4$, men = 3, age range: 46-70 y.o.), this distinction was specifically addressed. Participants were asked to complete two maps, one with the location of landfilled zones and the other with the location of disposal zones (Fig. 6). Five out of 7 participants of the second workshop stated that the football stadium and the football field with an athletic track are located on areas of material disposal, and 6 out of 7 stated that both the football stadium and the football field with an athletic track were built on landfilled zones. Thus, landfilled and disposal zones are apparently the same, but there were some cases in which inhabitants of Sibaté moved the disposed material to their homes to use it in the foundation or to level the floors. Because of this asbestos contamination in Sibaté may extend beyond the landfilled zones. The creation of landfilled zones seems to be initiated with the disposal of residue materials in topographic depressed zones, which was followed by material compaction. Then, infrastructure was built on top. 


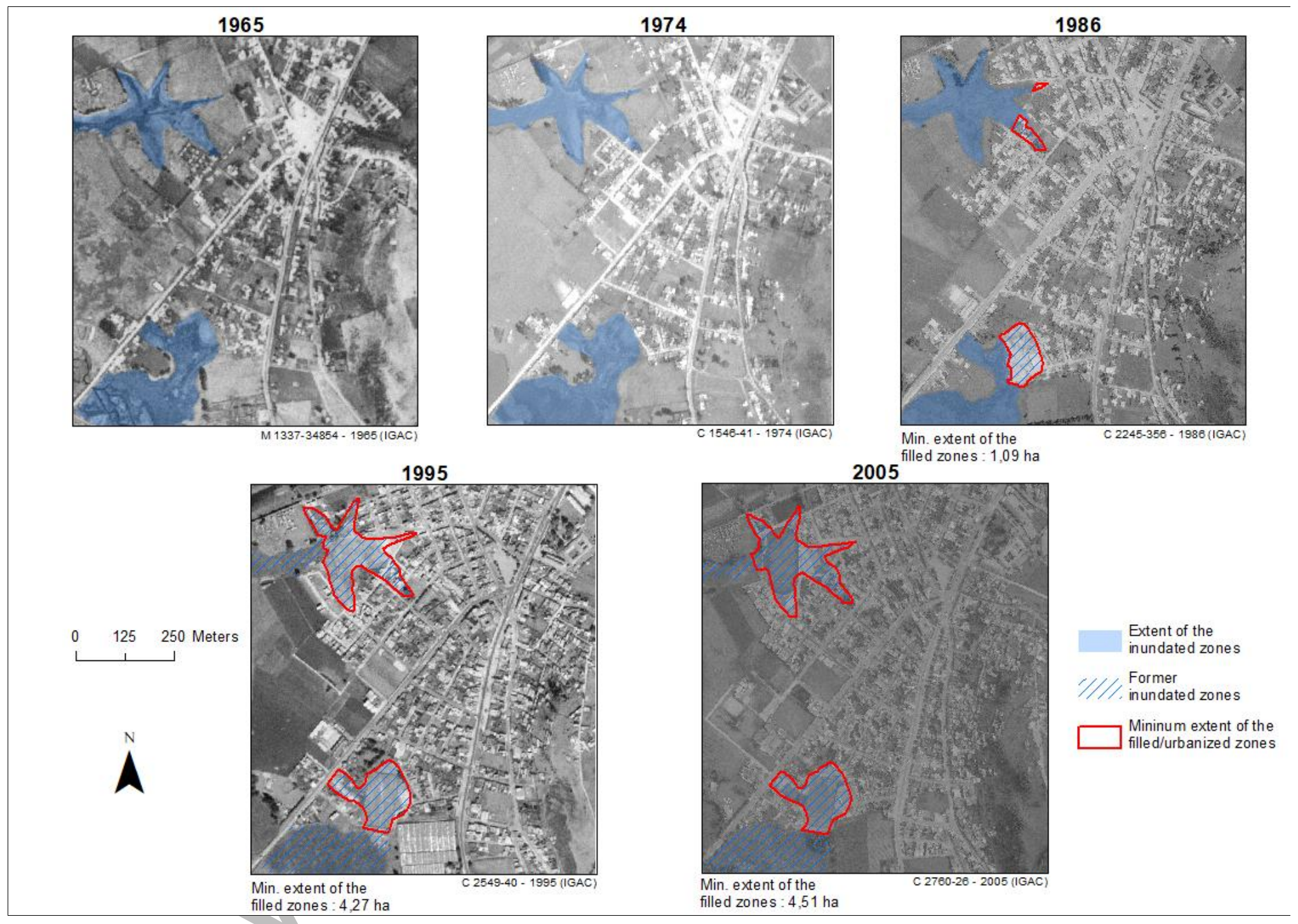

Fig. 4: Analysis of the desiccation of the reservoir's southern and western water intrusions in the urban area of Sibaté using aerial photographs 


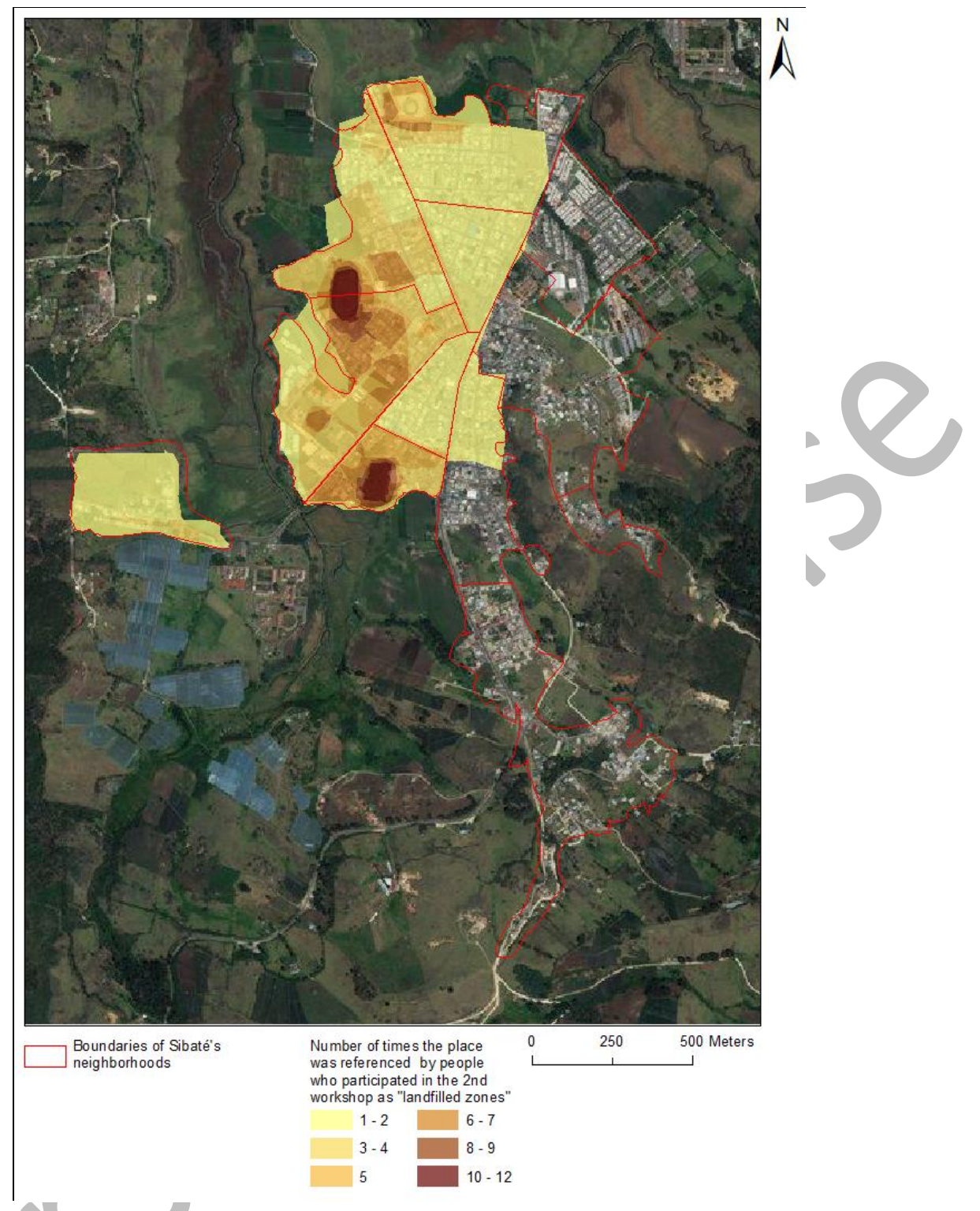

Fig. 5: Location of the landfilled zones according to the participants - First workshop

The information provided by the participants of both workshops regarding the location of the landfilled zones showed an important spatial correlation with what is observed on the aerial photographs. Additionally, participants reported the possibility of having asbestos contamination beyond landfilled zones, especially in the western part of the urban center of Sibaté.

Finally, samples opportunistically collected in four sites on October $19^{\text {th }} 2018$ from the slopes of excavations ordered by the municipality to replace underground pipelines located on landfilled zones confirmed the presence of an underground friable asbestos layer (Supplementary Material 4). The results of the laboratory analysis of the samples are shown in Table 1, and the location of the four samples is shown in Figure 1. 



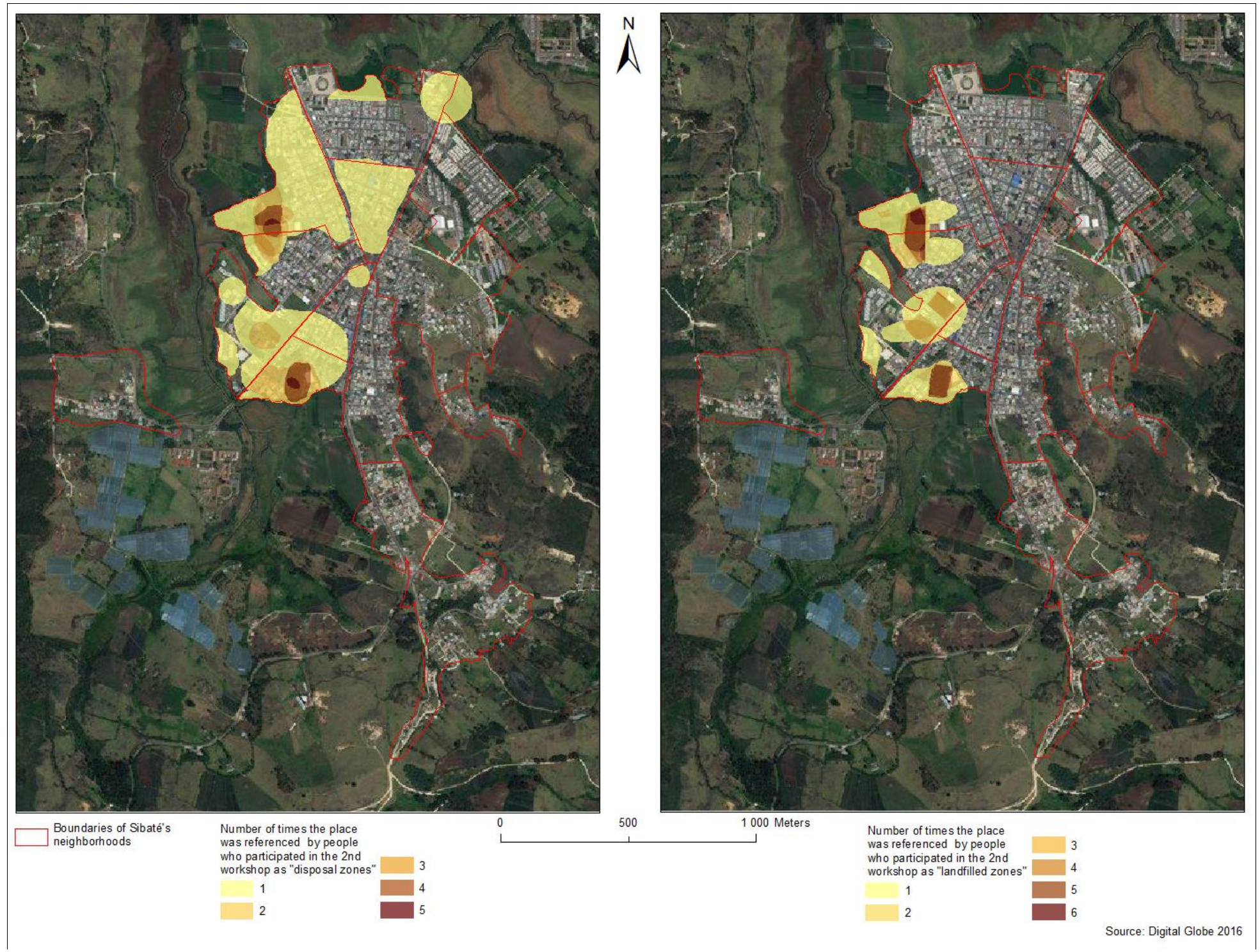

Fig. 6: Location of the "disposal zones" (left) and "landfilled zones" (right) according to the participants of the $2^{\text {nd }}$ workshop 
Table 1: Results of the opportunistic soil sampling campaign

\begin{tabular}{|c|c|c|c|c|c|}
\hline Sampling point & Type of sample & Sample depth $(\mathbf{c m})$ & $\begin{array}{c}\text { Asbestos layer } \\
\text { Thickness (cm) }\end{array}$ & Asbestos type & Asbestos content (\%) \\
\hline 1 & Sample of friable grey material & 64 & 13 & Chry / Cro & $10 / 5$ \\
2 & Sample of friable off-white material & 109 & 31 & Chry / Cro & $10 / 2$ \\
3 & Sample of friable grey material & 72 & 36 & Chry/Cro & $10 / 2$ \\
\hline 4 & Sample of dark brown soil & 65 & 38 & Chry & 2 \\
\hline
\end{tabular}

In three of the four sites where soil samples were collected, the layer of friable asbestos previously identified in other locations [11] was found (Table 1). The friable layer had a chrysotile content of 10 $\%$ in three samples, and a crocidolite content ranging from $2 \%$ to $5 \%$ (Table 1 ). The last sample was of dark brown soil with a chrysotile content of $2 \%$ (Table 1). The depth at which the friable layer was present in the three samples were it was found varies between $64 \mathrm{~cm}$ and $109 \mathrm{~cm}$ (Table 1). Furthermore, the thickness of the asbestos layer is not homogenous, and it ranges between $13 \mathrm{~cm}$ and $38 \mathrm{~cm}$ (Table 1).

\section{Discussion}

The current study improves our understanding of the location of landfilled zones in Sibate and the history of the creation of these zones, and confirms the presence of the underground friable asbestos layer in new sites within the urban area of Sibaté. The results indicate that for at least a decade, residues were disposed in several hectares of topographic depressed zones of the urban area of Sibaté (Fig. 7).

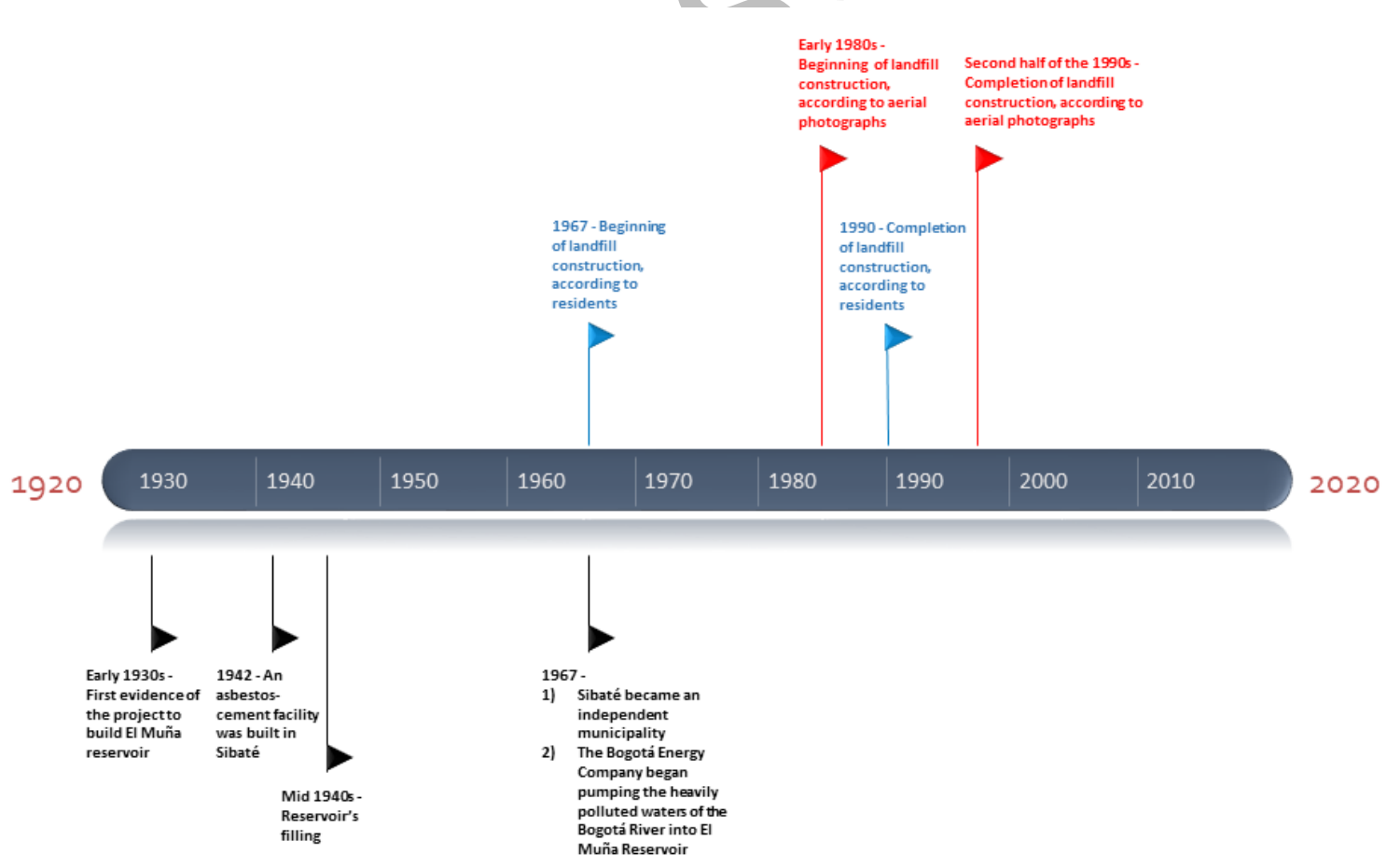

Fig.7: History of El Muña Reservoir and the construction of landfilled zones

Based on the information provided by inhabitants of Sibaté during two participatory workshops, the construction of the landfills lasted more than 25 years. Nevertheless, the analysis of aerial photographs (Fig. 4) suggests that the construction of the landfills may have lasted 10 years approximately, recognizing 
important time gaps between aerial photographs and their limitation to precisely capture all the deposition of residues that may have occurred in different moments in time. Moreover, the aerial photographs show that the construction of the landfills was still in progress in the mid 1990s, something that was not reported in the participatory workshops. Thus, in the process of reconstructing the history of the landfilled zones several sources should be used, recognizing the limitations that each individual source of information has.

Considering that soil samples collected in the current and previous studies confirmed the presence of an underground friable asbestos layer in specific sites of landfilled zones, during the disposal and subsequent compaction of these landfilled zones a major asbestos exposure source of the general population may have been created. The latency period of asbestos-related diseases determines that is crucially important to identify populations that were potentially exposed [39] [40] [41] [42] [43] [44], which can contribute in anticipating and preparing for future public health issues. It is important to highlight that a mesothelioma cluster has already been identified in Sibaté, with an important number of cases with no history of occupational asbestos exposure [11].

To understand the characteristics of the population of Sibaté when landfilled zones were built, the population pyramids for 1986 and 1995 were constructed using official population data from DANE (Fig. 7) [45]. Both pyramids are similar with an "expansive" shape, which means a high percentage of young people, reflecting a very high birth rate and a lower than average life expectancy since the foundation of Sibaté in 1967 [46]. The slight decline in birth rates observed in 1986 is reflected a decade later in the age groups between 10 and 19 y.o. in the 1995 pyramid. However, the birth rate seems to be on the rise again by 1995. For both 1986 and 1995, young people are the majority of the population in Sibaté. In 1986, children under 10 y.o. accounted for $24.04 \%$ of the population and the population under 25 y.o. was $56.4 \%$. In 1995, 24.65\% of the population was younger than 10 y.o., and $51.2 \%$ was younger than 25 y.o.. The peak of both pyramids, which is quite slender, indicates a relatively low average longevity in Sibaté. Based on the 1985 census, in Sibaté in 1986 women 60 years and older represented $3.12 \%$ of the population and men of the same age represented $2.96 \%$ of the population, while in Colombia and for the same age group women represented $7.3 \%$ of the population and men represented $6.7 \%$ of the population [47]. The high proportion of young people during the construction of the landfilled zones could help explain the large number of MPM cases diagnosed at unusual young ages in Sibaté [11], for a disease for which the median age at diagnosis is known to be above 60 y.o. [48][49]. A potential explanation for this finding is an asbestos environmental exposure that occurred at early childhood for these mesothelioma cases. In addition, the relatively short life expectancy indicated by the age pyramid suggests that some inhabitants of Sibaté may have died before the onset of mesothelioma. Thus, the health situation could be more critical than the one emerging from data described in the previous study [11], since many cases may have been missed. This information can be combined with the low men:women ratio of mesothelioma cases and it is also reinforced by the anamnesis on the type of asbestos exposure (i.e., no cases with occupational asbestos exposure). All together, these data reinforce the evidence of a cluster of mesothelioma cases associated to environmental asbestos exposure. 


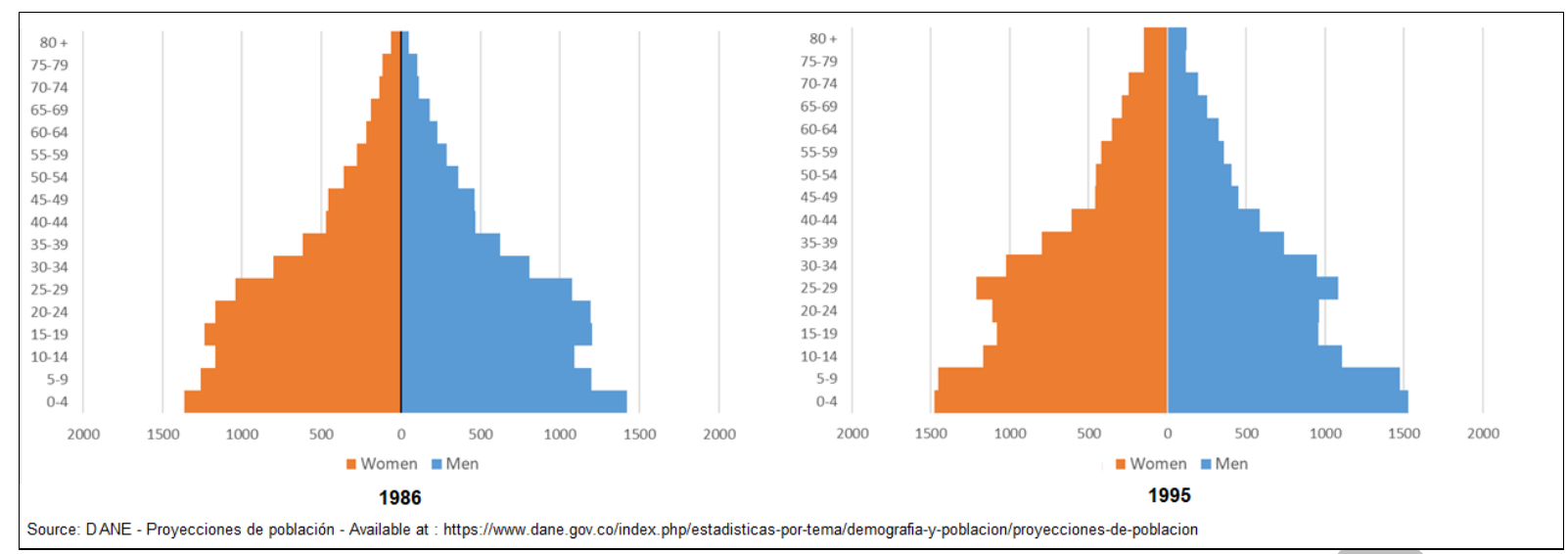

Fig. 8: Age-sex pyramids of Sibaté in 1986 and 1995

Combining the methods used in the current study with the methods applied in a previous study [11], we propose the following steps for a preliminary location of landfilled zones, if an analysis of this sort is going to be conducted in other cases similar to the case-study of Sibaté:

1) Identify and analyze, if available, historical documents that describe land use changes in the region. Furthermore, consult local authorities regarding the evolution of the cadaster and other information sources that could inform the location of landfilled zones. Historical photographic information, usually found in national archives, should be analyzed to determine if land use changes in the region could be identified,

2) Compile all the available geographic information for the area of interest (e.g., Old and current topographic maps, digital elevation model, satellite images if available),

3) Obtain the "source" material for the topographic maps (i.e., aerial photographs),

4) Implement participatory workshops with local inhabitants, with particular attention to foster the scientific methods of the workshops, in order to complement and validate the results of diachronic interpretation of maps and aerial photographs,

5) Integrate, geo-reference and cross all the available spatial information in a geographic information system to preliminarily determine the location of the target areas,

6) Combine all the previous information to elaborate preliminary maps of the potential location of landfilled zones. In the case-study of Sibaté, the desiccation of water intrusions allowed for a more refined analysis to classify the landfilled zones into "probable" or "possible" [11]. Figure 9 shows the location of "probable" landfilled zones, in what used to be inundated zones, and where currently sports facilities are in operation.

It is important to clarify that although the previous method results in valuable information regarding the location of landfilled zones potentially contaminated with hazardous residues (i.e., in this case asbestos), the boundaries of the landfilled zones determined using this approach may still have discrepancies compared to the real boundaries. A clear example of this can be illustrated by overlaying the geographic coordinates of the four soil samples opportunistically collected in the framework of the current study (i.e., marked as red points in Fig. 9) with the "probable" landfilled zone that corresponds to a former inundated zone. The boundaries of this landfilled zone were determined using the aerial photograph of 1974 (Fig. 9). The geographic coordinates of two of the four samples are located outside the boundaries of the landfilled zone, and since in these samples the presence of the underground layer of friable asbestos was confirmed, it can be concluded that 
the real boundaries of this landfilled zone extend beyond the limits determined using the aerial photograph. Thus, caution should be applied when using these results since the boundaries determined could still miss areas where hazardous materials are present. Depending on the characteristics of the residues present in landfilled zones, direct and invasive methods including soil sampling campaigns could be an option to delimit their boundaries [50] [51]. In the specific case of Sibaté, the presence of friable asbestos represents a risk of exposure that prevented us from using invasive methods. Therefore, the risk of exposure to hazardous materials is something that should be analyzed in detail when deciding what strategies are going to be implemented to determine the location of landfilled zones. We are currently exploring the possibility of using different non-invasive methods to improve our understanding of the location of the landfilled zones and the underground friable asbestos layer, something critical for risk management purposes. In addition, the use of stereoscopy on aerial photographs is another technique that could be applied in the future to determine topographic changes and complement the findings of the current study.

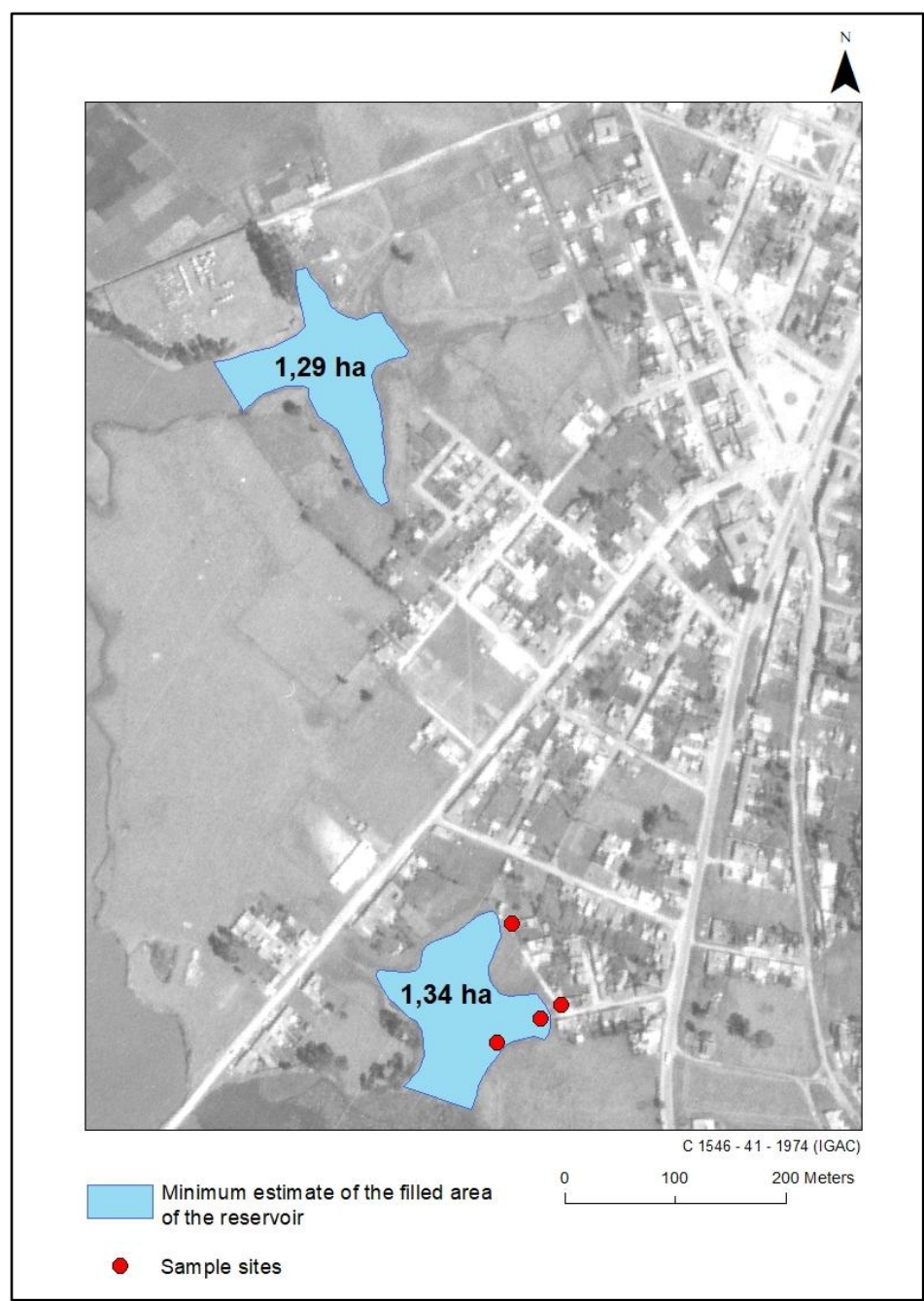

Fig. 9: "Probable" landfilled zones and specific sites where the opportunistic soil sampling campaign was conducted

Three hypotheses could explain the discrepancy presented in Fig. 9:

1) The disposal of residues occurred before the time-window hypothesized (i.e., late 1980s and mid 1990s), outside of what has been identified as a "probable" landfilled zone; 
2) Roads and paths that can be seen in aerial photographs and maps from the 1970s, were built on or leveled with residue materials before the time-window hypothesized;

3) The residue disposal was done in a larger area extending beyond the topographic depression.

It is important to bear in mind that aerial photographs are a snapshot and as a result, they do not capture the spatial-temporal dynamics induced by anthropogenic or natural factors. Furthermore, seasonal variations of the extent of El Muña Reservoir are not captured in a single aerial photograph. Therefore, the blue areas presented in Figure 9 have the uncertainties resulting from the limitations derived from the use of aerial photographs.

During the participatory workshops local residents explained that when residue materials were disposed, some inhabitants moved the materials to their dwellings, to level the floors and/or for building the foundations of their homes. Although the link between the asbestos-cement facility and the deposits observed in Sibate has not yet been established, it is important to comment that the situation in Sibaté shows strong similarities with what has been observed in Casale-Monferrato (Italy) and Australia, where asbestos production residues (i.e., polverino - dust) were disposed in public spaces and private properties [52] [53] [54]. Hence, asbestos-contaminated sites could also be present outside of what has been preliminary identified as landfilled zones. This further confirms the importance to adopt a participative research methodology and the effectiveness of engaging the Sibaté residents to foster a bidirectional transfer of information concerning the local context to support scientific studies. Furthermore, in order to reduce biases in the correct understanding and use of scientific terms by the Sibate inhabitants, as in the case of "landfilled zones" and "disposal zones", it is critical to establish a preliminary informative dialogue between researchers and residents involved to increase their environmental and asbestos literacy, allowing the acquisition of a common language to facilitate the exchange of information during the participatory workshops.

The total asbestos ban approved in Colombia in June 2019 [55] does not solve the negative legacy that resulted from the extensive use of asbestos in the country for nearly 80 years. Sibaté is an emblematic case that could contribute in solving the challenges that Colombia will face in the coming decades. The global elimination of asbestos-related diseases, which several international organizations are calling for, requires a systematic identification of both contextual sources of asbestos exposure and its health related impacts. In this sense, Sibaté can be a pilot case, in the noble sense of the term, for identifying and managing extremely poorly documented contamination processes.

This research raises new questions that need answers: Where did the asbestos-contaminated residues come from? What asbestos exposure sources and pathways may have been created during the construction of the landfilled zones? What members of the population experienced the highest risk of exposure? Which are the exact boundaries of the landfilled zones? Are non-invasive soil characterization tools an option to determine the boundaries of the landfills and the underground friable asbestos layer? Are there additional asbestos contaminated areas in Sibate outside landfilled zones? Are residents of Sibaté still experiencing asbestos exposure, and if the answer is yes, which are the sources? How to improve asbestos and environmental health literacy among Sibate residents for reducing their potential asbestos exposure? Answering these questions may aid in the design of risk management strategies for Sibaté, including a tailored communication plan.

\section{Conclusion}

This article proposes a combination of different techniques and multiple information sources to improve our understanding of the asbestos contaminated areas in Sibaté, especially those that were 
created in zones that were previously inundated. In this study the location of these contaminated zones is refined, and the timeline of the events that lead to the creation of these zones is presented. Because a friable asbestos layer was previously discovered in Sibaté, the proposed methodology does not include invasive techniques that could potentially disrupt the asbestos layer, dispersing the fibers.

The combination of cartographic and aero-photographic data with the spatial knowledge of inhabitants of Sibaté were used to determine that residue materials were deposited in two wetlands and subsequently leveled. It was also reported that in some occasions residues were transferred by inhabitants of Sibate from the original disposal areas to private dwellings, which means that the location of asbestos and other pollutants could be more diffuse in the urban area of Sibate than it was originally thought. Furthermore, the chronology of events shows that the southern inundated zone was filled before the western inundated zone. Analyzing aerial photographs from different moments in time, it is estimated that the largest operations of disposal of residues in inundated zones may have occurred for a period ranging between 10 to 15 years, ending in the second half of the 1990s. It is possible that additional residue disposal events occurred in other years, since some residents of Sibaté estimate that these activities lasted approximately 25 years, ending at the beginning of the 1990s. Evidence of the existence of the friable asbestos layer at new locations within the urban area of Sibaté highlights the importance of elaborating and implementing a risk management plan to prevent future exposures of the general population to this hazardous material. The use of additional non-invasive methods to improve our understanding of the location of both the landfilled zones and the friable asbestos layer is strongly recommended.

Anecdotally, one of the main questions that motivated the current study was "where are the landfilled zones?" From the work of the engineer and historian Miguel Triana, Sibate means, in Muisca language, "derrame de la laguna", which could be translated as "the overflow of the lagoon" [15].

Hence, where are the landfilled zones? Literarily, they are in Sibaté.

\section{Conflict of Interest}

Benjamin Lysaniuk, María Fernanda Cely-García, Agata Mazzeo, Daniela Marsili, Roberto Pasetto, Pietro Comba and Juan Pablo Ramos-Bonilla have no financial conflict of interest to declare. Pietro Comba served as expert witness in asbestos-related trials. Juan Pablo Ramos-Bonilla provided expert opinion in the Colombian Senate in the discussion of a Law banning asbestos in the country.

\section{Credit authorship contribution statement}

Benjamin Lysaniuk: funding acquisition, data and map analysis, sampling campaigns, writing - review \& editing. María Fernanda Cely-García: funding acquisition, sampling campaigns, data analysis, writing - review \& editing. Agata Mazzeo: writing - review and editing. Daniela Marsili: writing review and editing. Roberto Pasetto: writing - review and editing. Pietro Comba: review and editing. Juan Pablo Ramos-Bonilla: funding acquisition, sampling campaigns, data analysis, writing - review \& editing.

\section{Acknowledgments}

First, we want to acknowledge our Italian colleagues Corrado Magnani for his involvement in the initial discussion of this study, and Benedetto Terracini for reviewing the article and for his valuable comments that improved it. We want to thank the participants of the workshops for their valuable contributions to this study. This study would not have been possible without the information you 
kindly shared. We want to thank Sandra Córdoba, Principal of the "General Santander" School in Sibaté, for her support to the first participatory workshop and her support for the entire project. We would like to thank the technical staff of the Codazzi Geographical Institute who helped in collecting relevant geographic information used in this study. We want to acknowledge the undergraduate students from Universidad de Los Andes Alexandra García, María Camila Guerrero, Daniel Gómez, Vanessa Mesa, Nicolás Navarro, and María Paula Rincón. Finally, we want to thank Margarita María Giraldo Silva and María Camila Rodriguez García for their valuable involvement in this study, and Forensic Analytical Laboratories for the analysis of our samples.

\section{Funding sources}

This study was funded with internal funds of Universidad de Los Andes and COLCIENCIAS (Grant 784, 2017 for Postdoctoral Positions in Colombia for former Colciencias National Doctoral Students recipients, Contract FP44842-124-18), and a grant from the French ANR (program ERASEd - ANR-18CE03-0001-01).

\section{Ethics}

Universidad de Los Andes Ethics Committee approved the participatory workshops, and the collection, storing, and analysis of information and materials of the people that participated in this study.

\section{References}

[1] - INSERM (expertise collective). Effets sur la santé des principaux types d'exposition à l'amiante. Rapport. Paris, Les éditions Inserm, 1997, $434 \mathrm{p}$

[2] - Ramazzini C, Asbestos is still with us: Repeat Call for a Universal Ban. 2010.

[3] - Welch LS, and Lemen R. The worldwide pandemic of asbestos-related diseases. Annu Rev Public Health. 2013; 34: 205-16.

[4] - Doll R. Mortality from lung cancer in asbestos workers. British journal of industrial medicine. 1955; 12(2):81-6.

[5] - Selikoff IJ, Churg J, Hammond EC. The occurrence of asbestosis among insulation workers in the United States. Annals of the New York Academy of Sciences. 1965; 132(1):139-55.

[6] - Wagner JC, Sleggs CA, Marchand P.Diffuse pleural mesothelioma and asbestos exposure in the North Western Cape Province. British journal of industrial medicine. 1960; 17:260-71.

[7] - IARC. IARC Monographs on the Evaluation of Carcinogenic Risks to Humans. Asbestos (chrysotile, amosite, crocidolite, tremolite, actinolite, and anthophyllite. Volume 100C. 2012.

[8] - INRS. Dates clefs dans la connaissance et la prévention du risque amiante. Available from: https://www.google.com/url?sa=t\&rct=i\&q=\&esrc=s\&source=web\&cd=1\&ved=2ahUKEwiParrulb3nA hXt1FkKHfF0D1IOFjAAegQIBBAB\&url=http\%3A\%2F\%2Fwww.inrs.fr\%2Fdms\%2Finrs\%2FPDF\%2Famian te-dates-clefs\%2Famiante-dates-clefs.pdf\&usg=AOvVaw1gYqQpXoaVccbM7nYhg 1C [Accessed February 2020]

[9] - Ohar JA, Cheung M, Talarchek J, et al. Germline BAP1 Mutational Landscape of AsbestosExposed Malignant Mesothelioma Patients with Family History of Cancer. Cancer Res. 2016 Jan 15; 76(2): 206-15. 
[10] - Betti M, Aspesi A, Sculco M, Matullo G, Magnani C, Dianzani I. Genetic predisposition for malignant mesothelioma: A concise review. Mutat Res. 2019; 781:1-10.

[11] - Ramos-Bonilla JP, Cely-García MF, Giraldo M, Comba P, Terracini B, Pasetto R, et al. An asbestos contaminated town in the vicinity of an asbestos-cement facility: the case study of Sibaté, Colombia. Environmental Research. 2019; 176:108464.

[12] - Cely Garcia MF, Lysaniuk B, Pasetto R, Ramos Bonilla JP. Challenges Applying an Activity Based Sampling Methodology to Estimate the Cancer Risk Associated with Asbestos Contaminated Landfills. Environmental Research. 2019; 181:108893.

[13] - Eternit. Historia. Available from: https://www.eternit.com.co/web/eternit/historia. [Accessed July 2019].

[14] - DANE. Departamento Administrativo Nacional de Estadísticas. Available from: http://www.dane.gov.co/index.php/estadisticas-por-tema/demografia-y-poblacion [Accessed July 2019].

[15] - Alcaldía Municipal de Sibaté. Sibaté: pasado, presente y futuro. Available from: http://sibatecundinamarca.gov.co/MiMunicipio/Paginas/Pasado-Presente-y-Futuro.aspx. [Accessed July 2019].

[16] - Combariza Bayona DA. Contaminacion por metales pesados en el embalse del Muña y su relación con los niveles en sangre de plomo, mercurio y cadmio y alteraciones de salud en los habitantes del municipio de Sibaté (Cundinamarca) 2007. Tesis de grado, Universidad Nacional de Colombia, Facultad de medicina, Departamento de toxicología, Bogotá, 2009, 115p. Available from: http://bdigital.unal.edu.co/2341/1/597588.2009.pdf. [Accessed July 2019].

[17] - Roa Avendaño T, Llistar D. El caso del embalse del Muña - inversión pestilente en manos de ENDESA. Ecología política. 2005; 30:7-20.

[18] - Rodríguez Gómez JC, Acosta Peñaloza CE, Ramírez HH, Liliana N. Historia de la empresa de energía de Bogotá. Tomo 2 (1927-1959), Empresa de Energía de Bogotá s.a. e.s.p., Universidad externado de Colombia, Bogotá, 2000, 257p.

[19] - Soacha Ilustrada. Historia gráfica de Soacha (43). Available from: http://soachailustrada.com/2013/06/historia-grafica-de-soacha-43. [Accessed July 2019].

[20] - Islam Kahn N. Temporal mapping and spatial analysis of land transformation due to urbanization and its impact on surface water system: a case from Dhaka metropolitan area, Bangladesh. International Archives of Photogrammetry and Remote Sensing. 2000; 33(Part B7): 598605.

[21] - Bodea C, Ozunu A, Baciu N, Măcicăşan V. Using GIS in waste management - some conceptual considerations. ECOTERRA - Journal of Environmental Research and Protection. 2014; 11(1):61-65.

[22] - Valjavec MB. Detection of former landfills in gravel plain using geomorphometric analysis and high-resolution lidar dtm. Acta geographica Slovenica. 2000; 54(1):21-40.

[23] - De Wet A. Discovering and Characterizing Abandoned Waste Disposal Sites Using LIDAR and Aerial Photography. Environmental and Engineering Geoscience. 2016; 22(2):113-130.

[24] - Barnikel F. The value of historical documents for hazard zone mapping. Natural hazard and earth system sciences. 2004; 4:599-613. 
[25] - Gregory IN and Healey RG. Historial GIS: structuring, mapping and analysing geographies of the past. Progress in human geography. 2007; 31(5):638-653.

[26] - McCall MK. Participatory Mapping and Participatory GIS (PGIS) for CRA, Community DRR and Hazard Assessment. 2008. Geneva: ProVention. 13 p. Available from : http://proventionconsortium.net/themes/default/pdfs/CRA/PGIS Sept08.pdf. [Accessed July 2019].

[27] - Kienberger S. Participatory mapping of flood hazard risk in Munamicua, District of Búzi, Mozambique. Journal of Maps. 2014; 10(2):269-275.

[28] - Cronin SJ, Gaylord DR, Charley D, Alloway BV, Wallez S, Esau JW. Participatory methods of incorporating scientific with traditional knowledge for volcanic hazard management on Ambae Island, Vanuatu. Bull Volcanol. 2004; 66:652-668.

[29] - Cadag JRD, Gaillard JC. Integrating knowledge and actions in disaster risk reduction: the contribution of participatory mapping. Area. 2012; 44(1):100-109.

[30] - Mapedza E, Wright J, Fawcett R. An investigation of land cover change in Mafungautsi Forest, Zimbabwe, using GIS and participatory mapping. Applied Geography. 2003; 23:1-21.

[31] - Bauer K. On the politics and the possibilities of participatory mapping and GIS: using spatial technologies to study common property and land use change among pastoralists in Central Tibet. Cultural geographies. 2009; 16:229-252.

[32] - Jianchu X, Fox J, Vogler JB, Peifang Z, Yongshou F, Lixin Y, Jie Q, Leisz S. Land-Use and LandCover Change and Farmer Vulnerability in Xishuangbanna Prefecture in Southwestern China. Environmental Management. 2005; 36(3):404-413.

[33] - Candelo C, Ortíz GA, Unger B. Hacer talleres. Una guía práctica para capacitadores. 2003, Cali, Colombia: WWF Colombia.

[34] - Rubio Torgler H, Ulloa Cubillos A, Campos Rozo C. Manejo de fauna de caza, una construcción a partir de lo local. Métodos y herramientas. 2000, Bogotá, Colombia: Orewa, Fundación Natura, Ministerio del Medio Ambiente (UAESPNN), Organización de Estados Iberoamericanos-OEI, Instituto Colombiano de Antropología e Historia (ICANH), Fondo Mundial para la Naturaleza, Programa Colombia (WWF)

[35] - Honeycutt, D. More adventures in overlay: counting overlapping polygons with spaghetti and meatballs. ArcGIS Resources. ESRI. 2012. Available at: https://www.esri.com/arcgisblog/products/arcgis-desktop/analytics/more-adventures-in-overlay-counting-overlapping-polygonswith-spaghetti-and-meatballs/ [Accessed July 2019].

[36] - US EPA 600/R-93-116. Available at: https://www.nist.gov/system/files/documents/nvlap/EPA600-R-93-116.pdf [Accessed February 2020].

[37] - ASTM., ATSM D7521-16 Standard Test Method for Determination of Asbestos in Soil. 2016.

[38] - EPA. Soil Screening Guidance: User's guide. Second Edition. 1996 September 2017]; Available from: https://rais.ornl.gov/documents/SSG nonrad user.pdf

[39] - Liddel FD. Latent periods in lung cancer mortality in relation to asbestos dose and smoking. IARC Sci Publ. 1980;(30):661-5.

[40] - Cuccaro F, Nannavecchia AM, Silvestri S, Angelini A, Coviello V, Bisceglia L, Magnani C. Mortality for Mesothelioma and Lung Cancer in a Cohort of Asbestos Cement Workers in BARI (Italy). Time 
Related Aspects of Exposure. Journal of Occupational and Environmental Medicine. 2019; 61(5): 410416. doi: 10.1097/JOM.0000000000001580

[41] - Oddone E, Ferrante D, Tunesi S, Magnani C. Mortality in asbestos cement workers in Pavia, Italy: A cohort study. Am J Ind Med. 2017; 60: 852-866. https://doi.org/10.1002/ajim.22750

[42] - Ferrante D, Mirabelli D, Silvestri S, et al. Mortality and mesothelioma incidence among chrysotile asbestos miners in Balangero, Italy: A cohort study. Am J Ind Med. 2020; 63: 135-145. https://doi.org/10.1002/ajim.23071

[43] - Vimercati L, Cavone D, Lovreglio P, De Maria L, Caputi A, Ferri GM, Serio G. Environmental asbestos exposure and mesothelioma cases in Bari Apulia region southern Italy a national interest site for land reclamation. Environmental Science And Pollution Research. 2018; 25(16): 15692-15701.

[44] - Consonni D, De Matteis S, Dallari B, Pesatori AC, Riboldi L, Mensi C. Impact of an asbestos cement factory on mesothelioma incidence in a community in Italy. Environ Res. 2020; 183: 108968.

[45] - DANE. Departamento Administrativo Nacional de Estadística. Estimaciones de población 19852005 y proyecciones de población 2005-2020 nacional, departamental y municipal por sexo, grupos quinquenales de edad. Available at: https://www.dane.gov.co/files/investigaciones/poblacion/proyepobla06 20/Edades Simples 19852020.xIs [Accessed July 2019]

[46] - Richmond M. Population Pyramids. Available at: http://www.fsl.orst.edu/pnwerc/wrb/Atlas web compressed/5. Human Populations/5h.pyramids w eb.pdf [Accessed January 2020]

[47] - Ministerio de salud y protección social. Envejecimiento demográfico. Colombia 1951-2020 dinámica demográfica y estructuras poblacionales. Available at: https://www.minsalud.gov.co/sites/rid/Lists/BibliotecaDigital/RIDE/DE/PS/Envejecimientodemografico-Colombia-1951-2020.pdf [Accessed May 2020]

[48] - Tischoff I, Tannapfel A. Mesotheliom. Pathologe. 2017;38: 547-560. https://doi.org/10.1007/s00292-017-0364-z

[49] - Mazurek JM, Syamlal G, Wood JM, Hendricks SA, Weston A. Malignant Mesothelioma Mortality - United States, 1999-2015. MMWR Morb Mortal Wkly Rep. 2017;66(8):214-218. Published 2017 Mar 3. doi:10.15585/mmwr.mm6608a3

[50] - Frangi JP, Richard D. Heavy metal soil pollution cartography in northern France. Science of The Total Environment. 1997; 205(1): 71-79.

[51] - Leenaers H, Okx JP, Burrough PA. Comparison of spatial prediction methods for mapping floodplain soil pollution. Catena. 1990; 17(6):535-550.

[52] - Mazzeo A. Casale Monferrato is not the City of Asbestos; Casale Monferrato is the city that fights against asbestos! An exploratory study on the socio-political actions of going beyond suffering related to an environmental disaster caused by asbestos manufacturing. Master in medical anthropology, Amsterdam, 2012, Available at: http://amma.socsci.uva.nl/theses/mazzeo\%20agata.pdf [Accessed March 2020]

[53] - Rossi G. Amianto. Processo alle Fabbriche della Morte. Milano: Melampo, 2012, 160 p.

[54] - Gray C, Carey RN, Reid A. Current and future risks of asbestos exposure in the Australian 
community. Int J Occup Environ Health. 2016; 22(4): 292-299.

[55] - Congreso de Colombia. 2019. Ley 1968 de 2019. Por la cual se prohíbe el uso de asbesto en el territorio nacional y se establecen garantías de protección a la salud de los colombianos, Available at: https://dapre.presidencia.gov.co/normativa/normativa/LEY\%201968\%20DEL\%2011\%20DE\%20JULIO \%20DE\%202019.pdf [Accessed March 2020] 